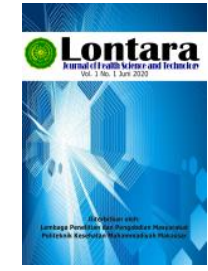

Lontara

Journal of Health Science and Technology

http://jurnal.poltekkesmu.online/lontarariset

Vol 2, No. 1, Juni 2021, pp 11-17

p-ISSN:0000-0000 dan e-ISSN: 2721-6179

DOI:https://doi.org/

\title{
POTENSI EKSTRAK ETANOL DAUN SIRIH (Piper betle L.) SEBAGAI PENGGANTI ADP (ADENOSINE DIPHOSPHATE) PADA PEMERIKSAAN AGREGASI TROMBOSIT
}

\author{
Andri Sukeksi, Rizqi Yogania Rahmawati \\ Program Studi D3, Fakultas Ilmu Keperawatan dan Kesehatan, \\ Universitas Muhammadiyah Semarang \\ Email: andri_unimus@yahoo.com
}

\begin{tabular}{l}
\multicolumn{1}{c}{ Artikel info } \\
Artikel history: \\
Received;01-03-2021 \\
Revised:10-03-2021 \\
Accepted; 13-05-2021 \\
\hline
\end{tabular}

Keyword:

Trombocyte aggregation, betel leaf (piper betle L), $A D P$ reagent (adenosine diphosphate).

Kata Kunci:

Agregasi trombosi, daun sirih (Piper betle L) reagen ADP (adenosine diphosphate).
Abstract. Adenosine diphosphate (ADP) reagent is often used in the examination of platelet aggregation, yet has limitations in terms of price and availability. Natural source namely betel leaf (Piper betle L.) are believed to be used as a substitute for ADP because betel leaf have the characteristics of styptic (to resist bleeding), vulnerary (to heal skin wounds), and anti-inflammatory (to preserve inflammation) (Moeljanto \& Mulyono, 2003). The aim of this study was to determine the potential of betel leaf on the examination of platelet aggregation. The method used in this research included the betel leaf extraction using ethanol as solvent with an evaporator. The extract obtained was used as a substitute for the ADP reagent in platelet examination in the form of determining the percentage of platelet aggregation in 16 human blood samples, with a population of students at the University of Muhammadiyah Semarang. The final results showed that the addition of betel leaf extraction to the 16 blood samples examined gave an average value of platelet aggregation percentage which was higher (65\%) than the mean value of platelet aggregation using ADP reagent mixing (57\%). Both results fall within the normal value range, namely 50-70\%. It can be concluded that betel leaf extract has the potential to be used as a replacement reagent for ADP in the process of examining platelets, especially in determining the percentage value of platelet aggregation.

Abstrak. Reagen adenosine diphosphate (ADP) digunakan untuk pemeriksaan agregasi trombosit, tapi reagen ADP harganya cukup mahal dan susah pengadaannya. Bahan alami yaitu daun sirih (Piper betle $L$ ) dapat digunakan sebagai pengganti ADP karena daun sirih mempunyai kandungan styptic (menahan perdarahan), vulnerary (mengobati luka pada kulit), dan mengurangi radang (Mengatasi inflamasi) (Moeljanto \& Mulyono, 2003). Tujuan penelitian mengetahui potensi daun sirih terhadap pemeriksaan agregasi trombosit. Metode yang digunakan dalam penelitian adalah metode ekstraksi daun sirih dengar pelarut etanol menggunakan evaporator. Ekstrak yang diperoleh digunakan sebagai pengganti reagen ADP dalam pemeriksaan trombosit berupa penentuan persentase agregasi trombosit pada 16 sampel darah manusia, dengan populasi 
mahasiswa/i Universitas Muhammadiyah Semarang. Hasil akhir penelitian menunjukkan bahwa penambahan ekstraksi daun sirih pada 16 sampel darah yang diperiksa memberikan nilai rerata persentase agregasi trombosit yang lebih tinggi 65\%) daripada nilai rerata agregasi trombosit menggunakan pencampuran reagen ADP (57\%). Kedua hasil tersebut masuk dalam rentang nilai normal yaitu 50-70\%. Dapat disimpulkan bahwa ekstrak daun sirih berpotensi ekstrak daun sirih berpotensi untuk dijadikan reagen pengganti ADP dalam proses pemeriksaan trombosit khususnya pada penentuan nilai persentase agregasi trombosit.

Coresponden author:

Email: andri_unimus@yahoo.com

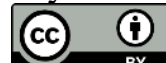

artikel dengan akses terbuka dibawah lisensi CC BY -4.0

\section{PENDAHULUAN}

Dalam hemostasis (penghentian perdarahan) tahap yang penting adalah penggumpalan trombosit. Sistem dalam tubuh yang mengatur supaya darah tetap mencair dan berfungsi Penghentian perdarahan dinamakan Hemostasis. Sumbatan pada pembuluh darah, penyempitan terjadi karena ada gumpalan darah, okulasi yang terbentuk pembentukan gumpalan darah menyebabkan strok infark akut. Penyebab no 1 kematian di dunia setiap tahunnya disebabkan karena stroke. Pada tahun 2013 data Riskesdas menunjukkan 12,1 per mil adalah prevalensi stroke nasional, tahun 2018 prevalensi stroke 10,9 per mil, tertinggi provinsi Kalimantan timur 14,7 per mil, terendah 4,1 per mil provinsi Papua (Kusumawati, 2018). Mursyid Bustami Direktur Rumah Sakit Pusat Otak Nasional (RSPON) mengatakan bahwa penyebab kematian nomer satu di Indonesia adalah stroke. Tahun 2018 stroke yang dulu tahun 90-an menduduki rangking kelima, sekarang rangking kesatu ini menurut riset kementerian. Untuk mengetahui kemampuan agregasi trombosit sangat perlu dilakukan sehingga mengetahui lebih awal terjadinya penggumpalan darah atau trombosit mulai beragregasi yang selanjutntya membentuk gumpalan. Pemeriksaan untuk mengetahui awal terjadinya agregasi trombosit menggunakan reagen ADP (Bustami, 2018).

Adenosin diphosphat (ADP) membantu Agregasi trombosit, Mekanisme agregasi trombosit diluar tubuh agregasi trombosit tidak aktif. Glikoprotein yang berada dalam permukaan trombosit mempunyai kandungan asam sialat sehingga mengakibatkan muatan negatif yang berakibat trombosit tidak dapat melekat bahkan menjadi saling berlawanan atau menolak. Trombosit dapat dirangsang dengan reagen ADP untuk membentuk agregasi. Disimpan dalam granula trombosit kemudian dilepaskan jika trombosit sudah diaktivasi.

ADP yang berada di dalam (trombosit P2Y1, P2Y12 dan P2X1) akan berinteraksi dengan reseptor ADP akan diubah menjadi adenosin oleh ecto-ADPase. Obat anti trombosit akan menghambat reseptor P2Y12. 
Proses koagulasi (proses penggumpalan darah) didalam tubuh diimbangi proses koagulasi. Antikoagulasi yang diberikan pada penderita tromboemboli berfungsi pembekuan darah dengan cara menghambat fungsi beberapa faktor pembekuan darah, agregasi trombosit adalah salah satu pemeriksaan koagulasi (Katzung, 2002). Pembentukan sumbatan trombosit melibatkan 3 tahapan yaitu: 1. Adhesi (proses pelekatan), 2. Reaksi Pelepasan, 3. Agregasi Trombosit (menggumpal). Tahapan pertama yaitu terjadinya proses pelekatan trombosit pada permukaan endotel/permukaan asing, kemudian reaksi pelepasan yaitu trombosit melepas ADP \& TXA2 agar trombosit saling menempel dan membentuk benang fibrin sehingga dapat menstabilkan massa trombosit (Katzung, 2002).

Sirih (Piper betle L.) adalah Tanaman obat di Indonesia dapat dimanfaatkan sebagai obat tradisional. Hal ini karena daun sirih mempunyai kandungan saponin, polifenol, minyak astiri, tannin dan flavonoid. Tannin dan flafanoid merupakan Senyawa utama berperan dalam proses pembekuan darah. Penelitian sebelumnya yang telah dilakukan oleh Tri Sutopo (2016) menunjukkan bahwa ekstrak etanol $70 \%$ dengan volume pemipetan sebanyak $10 \mu$ daun sirih mampu menghentikan perdarahan lebih cepat dan lebih efektif dibandingkan yang hanya diberi aquades dan eppinefrin sebagai bahan kontrol postif dan negatif.

Alkoloid, tannin, hidroksikaficol, kavicol, kavibetol, allyprokatekol, karvokrol, eugenol, Pcymene, cineole, coryofelen, kadimen, ekstragol, terpenana, dan fenilpropod adalah Kandungan senyawa kimia lain yang terdapat dalam daun sirih. Tannin sendiri memiliki kemampuan untuk membentuk kompleks dengan makromolekul terutama protein dinamakan sifat astringen. Kedua kandungan tersebut memiliki kemampuan dalam menghambat dan membuat trombosit yang beragregasi lebih banyak dibanding yang memakai reagen adenosin diphosphate (ADP). Kedua kandungan tersebut mampu menghambat metabolisme asam arakidonat oleh cyclooxygenase, dapat berpengaruh pada faktor pembekuan darah (Tri Sutopo, 2016) .

Di lapangan, peran reagen ADP sebagai induktor dalam pemeriksaan trombosit memiliki kelemahan yaitu harganya yang mahal, dan sulit diperoleh karena kebanyakan masih diimpor dari luar negeri. Tujuan penelitian adalah mencari pengganti ADP pada pemeriksaan agregasi trombosit dengan menggunakan bahan alami daun sirih (Piper betle L.) karena ADP sulit didapatkan.

\section{BAHAN DAN METODE}

Jenis penelitan yang dilakukan adalah penelitian deskriptif. Penelitian ini dilaksanakan di Laboratorium Hematologi Universitas Muhammadiyah Semarang. Penelitian dilakukan pada bulan Januari 2020 - Juni 2020. Variabel dari penelitian adalah Ekstraksi dari Daun Sirih (Piper betle L.) Populasi dalam penelitian adalah mahasiswa/i Universitas Muhammadiyah Semarang. Sampel yang digunakan dalam penelitian adalah darah vena dari 16 mahasiswa/i Universitas Muhammadiyah Semarang Semester 3 akhir D-III Analis Kesehatan dengan kriteria inklusi: perempuan, sehat dan 
tidak sedang mengkonsumsi obat apapun.

Alat penelitian yang diperlukan antara lain seperangkat alat maserasi evaporator (Labtech) blender (Philips), timbangan analitik (O’hauss), centrifuge (Gemmy PLC03), object glass (Sail brand), mikropipet (Human), yellow-tip dan white-tip (Axygen), kertas saring (Whatman), corong (Herma), waterbath (Wina), mikroskop (Olympus CX23), pipet pasteur (Citotes). Sedangkan bahan yang digunakan dalam penelitian adalah daun sirih (Piper betle L.), reagen adenosine diphosphate (ADP), etanol 70\%, darah vena, metanol, dan larutan giemsa. Sampling dilakukan sebanyak 16 kali dari 16 jumlah populasi yang diperoleh dari perhitungan besaran sampel (Supranto, 2011) diantaranya: (t-1) $(\mathrm{r}-1) \geq 15,(2-1)(\mathrm{r}-1) \geq 15,1(\mathrm{r}-1) \geq 15, \mathrm{R} \geq 16$.

Prosedur pemeriksaan trombosit pada prinsipnya dilakukan dengan reagen ADP dan dengan ekstrak etanol daun sirih. Darah dari spuit tadi dimasukkan ke dalam tabung vacum citras sebanyak 3 ml, kemudian homogenkan. Pada menit ke 0 darah citras dibuat sediaan apus darahtepi. Sisa yang ada ditambahkan reagen ADP dengan perbandingan $1: 10$, digoyang agar tercampur rata. Ditunggu 3 menit dan dengan pipet diambil 10 ul, pada menit ke 3 dibuat lagi sediaan darah tepi. Sediaan yang sudah dibuat ditunggu sampai kering dan kemudian difiksasi menggunakan methanol selama 5 menit kemudian dicat giemsa sampai 20 menit, dengan air mengalir sediaan dibilas dan biarkan sampai kering. Sediaan diperiksa di mikroskop perbesaran 100x dengan minyak imersi. Pada daerah lateral zona IV - VI pengamatan dilakukan. Hasil yang diperoleh dicatat dan dilaporkan.

Nilai normal Agregasi Trombosit:

$50 \%-70 \%$

Rumus:

koreksi Agregasi $=($ presentase agregasi total - pertama $) \times 100$

100 - persentase agregasi pertama

Prosedur pemeriksaan dengan penambahan ekstrak etanol daun sirih adalah sebagai berikut: Ekstrak etanol daun sirih dipipet sebanyak $10 \mu 1$ menggunakan mikropipet dan dimasukkan ke dalam tabung serologi. Sebanyak $100 \mu 1$ darah citras dipipet dimasukkan ke dalam tabung yang sudah berisi ekstrak etanol daun sirih tadi. dihomogenkan, kemudian dibuat sediaan apus darah tepi. Sediaan ditunggu sampai kering dan kemudian difiksasi menggunakan methanol. Selama 5 menit kemudian dicat giemsa selama 20 menit, lalu dibilas dengan air mengalir dan dibiarkan sampai kering. Diperiksa di mikroskop perbesaran 100x dengan minyak imersi. Pada ekor daerah lateral zona IV VI. Hasil yang diperoleh dicatat.

\section{HASIL PENELITIAN}

Pada penelitian ini ekstrak daun sirih digunakan sebagai reagen pengganti ADP dalam penentuan persentase agregasi trombosit sampel darah manusia. Proses ekstraksi daun sirih dilakukan dengan metode evaporasi dan ekstrak yang diperoleh ditunjukkan pada Gambar 1. Selanjutnya pemeriksaan trombosit berupa penentuan nilai persentase agregasi dilakukan pada 16 sampel darah 
Potensi Ekstrak Etanol Daun Sirih (Piper Betle L.) Sebagai Pengganti ADP (Adenosine Diphosphate) pada Pemeriksaan Agregasi Trombosit (Andri Sukeksi, Rizqi Yogania Rahmawati)

dari 16 pasien menggunakan ekstrak sirih yang diperoleh. Spesimen yang digunakan dalam penelitian yaitu darah vena mahasiswa/i Universitas Muhammadiyah Semarang sebanyak 3ml. Darah vena ditampung dalam wadah tabung vacum bertutup biru yang berisi natrium sitrat.
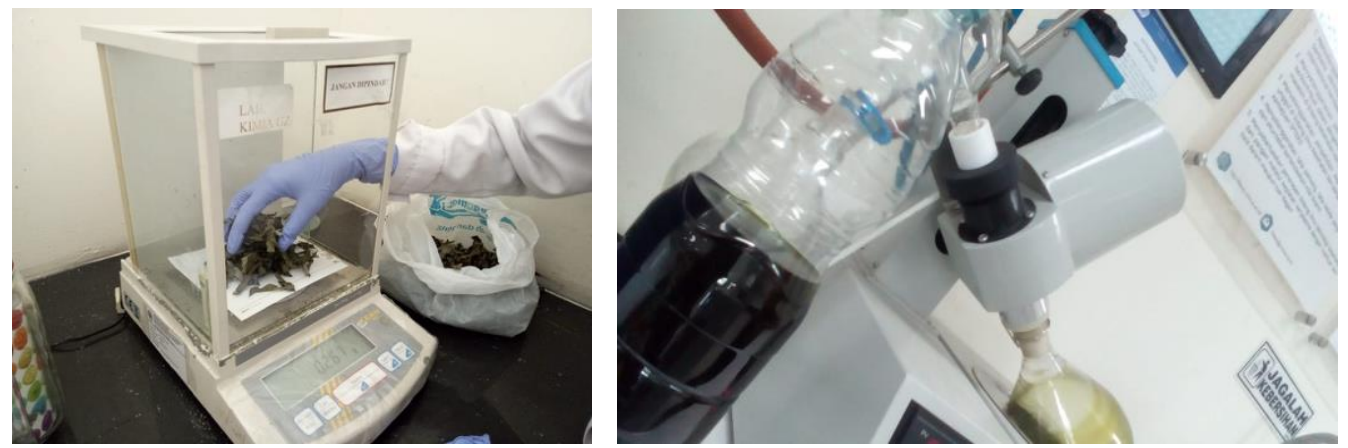

Gambar 1. Proses ekstraksi daun sirih dengan metode evaporasi dan hasilnya

Hasil pemeriksaan trombosit berupa persentase agregasi menggunakan perlakuan yang berbeda ditunjukkan pada Tabel 1 dan 2. Hasil yang diperoleh berdasarkan perbedaan penggunaan reagen, yang menggunakan adenosin diphosphate (ADP) memiliki nilai rerata 57\% sedangkan dengan ekstrak daun sirih (Piper betle L.) nilai reratanya 65\%. Nilai minimal hasil pemeriksaan dengan reagen adenosin diphosphate (ADP) 44\%, dengan ekstrak daun sirih 52\%. Nilai maksimal hasil pemeriksaan dengan reagen adenosin diphosphate (ADP) 69\%, dengan ekstrak daun sirih $77 \%$.

Tabel 1. Rerata hasil nilai agregasi trombosit antara penambahan reagen adenosine diphosphate (ADP) dan ekstrak daun sirih (Piper betle L.)

\begin{tabular}{|l|c|c|c|}
\hline \multicolumn{1}{|c|}{ Agregasi Trombosit } & Nilai min. & Nilai max. & Mean \\
\hline Dengan reagen ADP & $44 \%$ & $69 \%$ & $57 \%$ \\
\hline Dengan ekstrak daun sirih & $52 \%$ & $77 \%$ & $65 \%$ \\
\hline
\end{tabular}

Tabel 2. Gambaran pemberian daun sirih terhadap pemeriksaan agregasi trombosit

\begin{tabular}{|lll|}
\hline Responden & Dengan Penambahan Daun Sirih & Tanpa Penambahan Daun Sirih \\
\hline A & $52 \%$ & $56 \%$ \\
\hline B & $77 \%$ & $62 \%$ \\
\hline C & $66 \%$ & $57 \%$ \\
\hline D & $68 \%$ & $48 \%$ \\
\hline E & $70 \%$ & $44 \%$ \\
\hline F & $65 \%$ & $62 \%$ \\
\hline G & $69 \%$ & $55 \%$ \\
\hline H & $77 \%$ & $48 \%$ \\
\hline I & $68 \%$ & $53 \%$ \\
\hline J & $59 \%$ & $46 \%$ \\
\hline S & $73 \%$ & $65 \%$ \\
\hline L & $57 \%$ & $51 \%$ \\
\hline M & $59 \%$ & $61 \%$ \\
\hline N & $67 \%$ & $49 \%$ \\
\hline O & $63 \%$ & $58 \%$ \\
\hline P & $76 \%$ & $69 \%$ \\
\hline Rata-rata & $\mathbf{6 7 \%}$ & $\mathbf{5 5 \%}$ \\
\hline S & 6 & \\
\hline
\end{tabular}

Sumber : Data Primer, Nilai Normal : 50-70\% 


\section{PEMBAHASAN}

Hasil penelitian secara umum menunjukkan bahwa penggantian reagen ADP dengan ekstrak daun sirih memberikan nilai rerata hasil pemeriksaan trombosit (persentase agregasi) yang lebih tinggi bila dibandingkan nilai presentase agregasi trombosit rerata yang diperoleh dengan penggunaan reagen adenosine diphosphate (ADP). Hasil pemeriksaan (Tabel 1 dan 2) menunjukkan bahwa pemeriksaan agregasi trombosit dengan penambahan ekstrak etanol daun sirih memiliki kemampuan yang lebih signifikan yaitu trombosit yang beragregasi lebih banyak terlihat yang menggumpal dibandingkan tanpa penambahan ekstrak daun sirih. Hal ini diduga karena daun sirih memiliki kandungan yaitu flavonoid dan tannin dimana kedua kandungan tersebut memiliki kemampuan dalam menghambat dan membuat trombosit yang beragregasi lebih banyak dibanding yang memakai reagen adenosin diphosphate (ADP). Selain itu, flavonoid dan tanin pada daun sirih juga diketahui mampu menghambat metabolisme asam arakidonat oleh cyclooxygenase.

Secara umum, persentase agregasi trombosit sampel yang menggunakan ekstrak daun sirih memiliki nilai rata-rata lebih tinggi dibandingkan nilai dengan penambahan reagen adenosine diphosphate (ADP), dengan rentang nilai normal 50-70\%. Hasil tersebut sejalan dengan yang dilaporkan oleh Kusumawati (2018) yang menggunakan getah pelepah pisang sebagai pengganti ADP dalam pengukuran persentase agregasi trombosit. Hasil penelitian tersebut menunjukkan adanya perbedaan kemampuan agregasi trombosit antara reagen ADP dengan getah pelepah pisang raja. Lebih lanjut hasil penelitian menunjukkan bahwa prosentase agregasi trombosit menggunakan getah pelepah pisang raja lebih tinggi dibandingkan dengan ADP.

\section{KESIMPULAN DAN SARAN}

Pada 16 sampel darah yang diperiksa, nilai rerata persentase agregasi trombosit yang diperoleh menggunakan ekstrak daun sirih lebih tinggi 65\%) daripada nilai rerata agregasi trombosit menggunakan pencampuran reagen adenosin diphosphate (ADP) (57\%). Kedua hasil tersebut masuk dalam rentang nilai normal yaitu 50-70\%. Dapat disimpulkan bahwa ekstrak daun sirih berpotensi untuk dijadikan reagen pengganti ADP dalam proses pemeriksaan trombosit khususnya pada penentuan nilai persentase agregasi trombosit.

\section{UCAPAN TERIMA KASIH}

Penelitian ini didanai oleh hibah internal LP3M Universitas Muhammadiyah Semarang (UNIMUS) Tahun 2021. Penelitian ini sudah mendapatkan izin dari Komite Etik Fakultas Kesehatan Masyarakat, UNIMUS. 


\section{DAFTAR PUSTAKA}

Anisa Kusumawati. Perbedaan agregasi trombosit antara reagen adenosin difosfat (ADP) dengan getah pelepah batang pisang raja (Musa sp.) [manuscript]: Universitas Muhammadiyah Semarang; 2018

Mursyid Bustami, Direktur rumah sakit pusat otak nasional ( RSPON) riset kesehatan kementrian kesehatan pada 2018.

Hoffbrandd AV, Petit JE. Trombosit, blood coagulation and haemostasis. In: Essential haematology. 3rd ed. Oxford: Blackwell Science, 1993; 299-17.

Katzung, B.G. 2002. Farmakologi Dasar dan Klinik. Jakarta: Salemba Medika. 1103

Thrombocythemia and Thrombocytosis - National Heart, Lung, and Blood Institute. (n.d.). Retrieved August 12, 2020, from https://www.nhlbi.nih.gov/health-topics/thrombocythemia-andthrombocytosis\#: :text=Thrombocythemia\%20(THROM\%2Dbo\%2Dsi,other\%20kinds\%20of \%20blood\%20cells.

Tri Sutopo. 2016. Uji Ekstrak Etanol 70\% Daun Sirih (Piper betle L.) Terhaadap Bleeding Time Pada Mencit Jantan Galur Swiss Webster, Skripsi. Fakultas Kedokteran Universitas Muhammadiyah Surakarta, Surakarta.

Wirawan- R. Uji ketelitian dan nilai rujukan agregasi trombosit dengan agonist ADP pada orang dewasa Indonesia penerbit FKUI 2008 